\title{
Life Cycle Analysis of the panela agroindustry: Intensification for its development
}

\author{
Walter Francisco Quezada Moreno ${ }^{1}$; Walter David Quezada Torres ${ }^{2}$; Erenio González \\ Suárez ${ }^{2}$; Marcia Judith Torres Tambo ${ }^{2}$; Franklin Antonio Molina Borja ${ }^{1}$; Nancy Fabiola \\ Moreano Terán ${ }^{1}$; Amaury Pérez Martinez ${ }^{3}$
}

\author{
${ }^{1}$ Department of research, Universidad Técnica de Cotopaxi. Latacunga, Ecuador. \\ ${ }^{2}$ Department of Chemical Engineering. Universidad "Marta Abreu" de Las Villas. Santa Clara, Cuba. \\ ${ }^{3}$ Department of research, Universidad Estatal Amazonica. Puyo, Ecuador.
}

\begin{abstract}
The research made it possible to identify sensitive environmental factors generated in all the operations carried out in an intensified panela agroindustry for the purposes of diversification, productivity, quality and safety. Results of the Environmental Impact Assessment (EIA), according to the Life Cycle Analysis (LCA) methodology show that in all impact categories, the industrial stage of the production of honey, panela and sugar, cause greater environmental impact, being the two latter the most representative. However, according to the Ecuadorian environmental legislation, the impacts of the panela agroindustry are considered to be moderate and cataloged type II, therefore it does not require intensive corrective practices. However, it requires preventive actions aimed to mitigate impacts, considering that it is a subsector of the sugar cane industry that is present as production units throughout the country, where there are favorable conditions for the cultivation of sugar cane.
\end{abstract}

Keywords- Agroindustry panelera, Sweeteners, Intensification, Environmental assessment.

\section{INTRODUCTION}

The traditional, artisanal and inefficient way used in the processes of producing sweeteners from sugar cane in the panela agroindustry affects the productivity, quality and safety of the final product. However, globalization and increasingly demanding quality product markets promote a common approach based on an intensification of the processes [1], an approach that has emerged as an intelligent engineering discipline in the field of scientific research and advancement in industrial processes. Cleaner and more efficient productions that allow improvements in the general processes can be included in the panela agroindustry, as an action for business development. These productions are safe, economical and necessary for the sustainability of a technological and organizational process. The sugar cane industry is aimed at developing productive activities that comply with the technical obligations of the environmental legislation.

In that sense, environmental assessments are valid in the business and governmental world since they have turned into actions to understand and manage the risks and opportunities for the introduction of scientific knowledge through the Life Cycle Analysis of a product or process, in order to diminish their impact on the environment during the production process. The new applications of this knowledge, are effective to solve problems of sustainability and, necessary for the quality of life and sustainability of a company.

\subsection{Panela agroindustry}

The purpose of the panela agroindustry in Ecuador is to develop productive activities from the cultivation, processing of sugar cane and commercialization of its by-products such as honey, panela and natural sugar, as well as biomass. The panela industry transforms sugar cane juice into a solid product, known as panela, which is considered an important sweetening agent in the diet of Ecuadorians because of its characteristic taste and nutritional value [1][2]. If this industry is so important in terms of high employment multiplication and product value addition [3] [4] then it is necessary to optimize resources for its modernization and development, while increasing job opportunities. It is estimated that there are 610 units of panela production in the country that use as bagasse, firewood, tires and chemicals as fuels in the technological process for juice clarification [1][5].

In this industry, artisanal activities still prevail rather than industrial activities, due to the use of rudimentary practices in the manufacturing process, which have limited its development. On the other hand, the lack of control and 
application of the regulations contained in the environmental legislation, have made the activity be considered hardly ecofriendly. Thus, the lack of management, technology and improvements in its processes have led to low productivity, competitiveness, quality and safety of its products. All these problems have an impact on the environment and led to the search of feasible alternatives for intensifying the industrial processes and diversifying the panela industry production for productivity and sustainability.

The quality and safety of its products, the competitiveness and the development of the industry must be fully justified by actions of continuous improvement and innovative efforts for using clean and safe production [6]. Despite the importance of the sugar cane industry and the existence of an environmental legislation, the compliance with technical and environmental obligations is not always fulfilled in the panela industry, affecting its development and impacting the environment. Hence, innovative efforts are required from the technical-economic and environmental point of view to achieve improvements with fewer resources, which must be environmentally assessed to favor their investment and secure the market.

\subsection{Intensification of industrial processes}

The quality, safety, profitability, productivity and competitiveness, support the stability of the products in the global market; therefore, it is necessary to introduce scientific and technological development to move from the traditional and artisanal practices to the industrial ones with a focus on sustainability.

Intensification of Processes consists of the development of innovative equipment and techniques that offer substantial improvements in the production process, by reducing the volume of equipment, energy consumption and waste generation, resulting in cheaper, safer and sustainable technologies [11] [12] [13]; it is a revolutionary approach of development to process and design a plant [14], with industrial creativity including Research and Development techniques [15].

Intensification seeks to improve traditional processes, but the environmental impact is imminent and for doing this some actions are required to mitigate it. A balance between production and consumption is needed and it can be largely achieved with a responsible attitude of all the actors involved in the market [7]. Intensification of Processes (IP) develops safe actions, with highly efficient equipment, reduced in size that allows to obtain greater productivity with less amount of raw material and waste generation. It is important that the intensification of processes continues to be carried out and organized, so that the new generations could collaborate to develop technologies by promoting innovations and contributions to industry [8] [9] [10].

Leading scientists in the industry and in the US academic settings outline seven key issues to strengthen the development of these changes: reducing capital investment, reducing energy use and raw material costs, increasing flexibility in the process and reduction of the investments, increasing the safety of the process, increasing the attention to the quality and improvement of the environmental performance [16] [17]. Most entrepreneurs argue that increasing global competition will require significant changes in the way plants are designed. So, knowing how to understand and define the IP to achieve efficiency and productivity is imperative for the engineer and entrepreneur. The IP is necessary and consists of research actions and innovations development to optimize the processes in the different stages to obtain a quality product or service, through cleaner and safer productions that are reverted in satisfaction and social welfare. People committed to the development of scientific research and technological progress should prioritize improvement and evaluation processes, which guide the application of intensification processes and environmental assessment alternatives with a comprehensive approach, through the Life Cycle Analysis (LCA).methodology.

\subsection{Environmental assessment of the Panela Agroindustry}

There is widespread concern of reducing the environmental effects caused by economic activities at the global level. Research led by Rememen Arne and colleagues point out that the aim is to minimize the environmental impacts of a product or service from their portfolio throughout their entire life cycle [18]. LCA is a tool that can be applied in the optimization of production systems, improving market competitiveness through policies and practices that improve or increase sustainability [19]. LCA is the collection and evaluation of inputs and outputs and the potential environmental impacts of a product system throughout its life cycle [20].

It is a new way of applying knowledge, which allows to solve existing environmental problems generated throughout the production chain to achieve significant improvements in intensification processes. Assessing the sustainability of policies, processes, products and actions requires addressing this concept in depth, avoiding a fragmented vision by applying the Life Cycle Approach, a form of analysis that goes beyond the traditional approach to include 
environmental, social and economic impacts throughout the life cycle. The life cycle of a product begins with the extraction of the raw material from its natural sources and the generation of energy necessary for all manufacturing processes (transportation, production, packaging, distribution, use, maintenance, etc.) to eventual recycling, reuse, recovery or final disposal.

This process requires an infrastructure that reduces environmental impact. Adequate planning in the protection of the environment is necessary as the main factor to guarantee the quality and safety of the product, the health of the community and good life standards.

The increasing recognition of environmental protection and the potential impacts associated with the manufacture and consumption of products has increased the interest in developing methods for the evaluation and reduction. The LCA studies the environmental aspects and the potential impacts throughout the life cycle of a product or process [21]. Defining and categorizing the industry as well as assessing the environmental effects generated throughout the production chain, supports the evaluation of the LCA. ISO 14040 defines the "life cycle" as the consecutive and interrelated stages of a product system, from the acquisition of raw material or its generation from natural resources to the final disposal [22].

The Mexican Center for Cleaner Production also defines LCA as a tool that establishes market strategies and helps to plan prevention activities to achieve cleaner production in the industry [23]. In fact, LCA is an internationally accepted and recognized methodology for the evaluation of environmental loads and impacts associated with the elaboration of a product or process, taking into account all the stages of their life [24]. It means to reduce the consumption of resources necessary for the elaboration of a product and also emissions to the environment; it is the management of sustainability of the supply chains. Eventually, LCA, is fundamental in daily decision making [25], to make better use of resources since every productive activity is prone to generate negative environmental impacts.

Thus, it is significant for the agroindustrial sector, to pass a law that promotes its development, contributing to food security and sovereignty for good living standards, through a safe and permanent access to healthy and nutritious food [26] [27] [28].

According to Annex I of the National Environmental Categorization Catalog (NECC), for the construction and and/or operation of factories for the production of panela, this industry is categorized in group II, considered of low impact, therefore it requires an environmental record [29]. Despite the non-compliance and lack of environmental control in this industry, the use of bagasse as fuel material, less costly for industries as well as wood and tires, cause harmful environmental effects.

\section{MATERIALS AND METHODS}

A bibliographical review of the sector was carried out and data were collected to evaluate the environmental impact of an intensified panela industry with improvements in each stage of the process and optimization of by-products such as cachaza and bagasse in the production of alcohol and as nutritional supplement for animals. The optimization in each of the stages of the process, allowed the intensification in the industry, increasing the production capacity from 20 to $30 \mathrm{t}$ cane / day with a $65 \%$ extraction. Meanwhile, diversification paved the way for the development of new products with and without aromas according to different variants: Variant 1: hydrolyzed honey (50\%) - panela (50\%); Variant 2. hydrolyzed honey (50\%) - natural sugarcane (50\%); Variant 3. panela $(50 \%)$ - natural sugarcane $(50 \%)$; Variant 4 . honey $(30 \%)$ - panela $(35 \%)$ - natural sugarcane $(35 \%)$.

The environmental assessment was performed using the LCA methodology and the software Simapro7. The intensification was initiated by applying mass and energy balances and the input and output inventory of materials that triggers the production process. The combustion of gases was measured using the E-instrument 4400. The limits of the system in the agricultural and industrial stages were assessed and are shown in figure 1. 


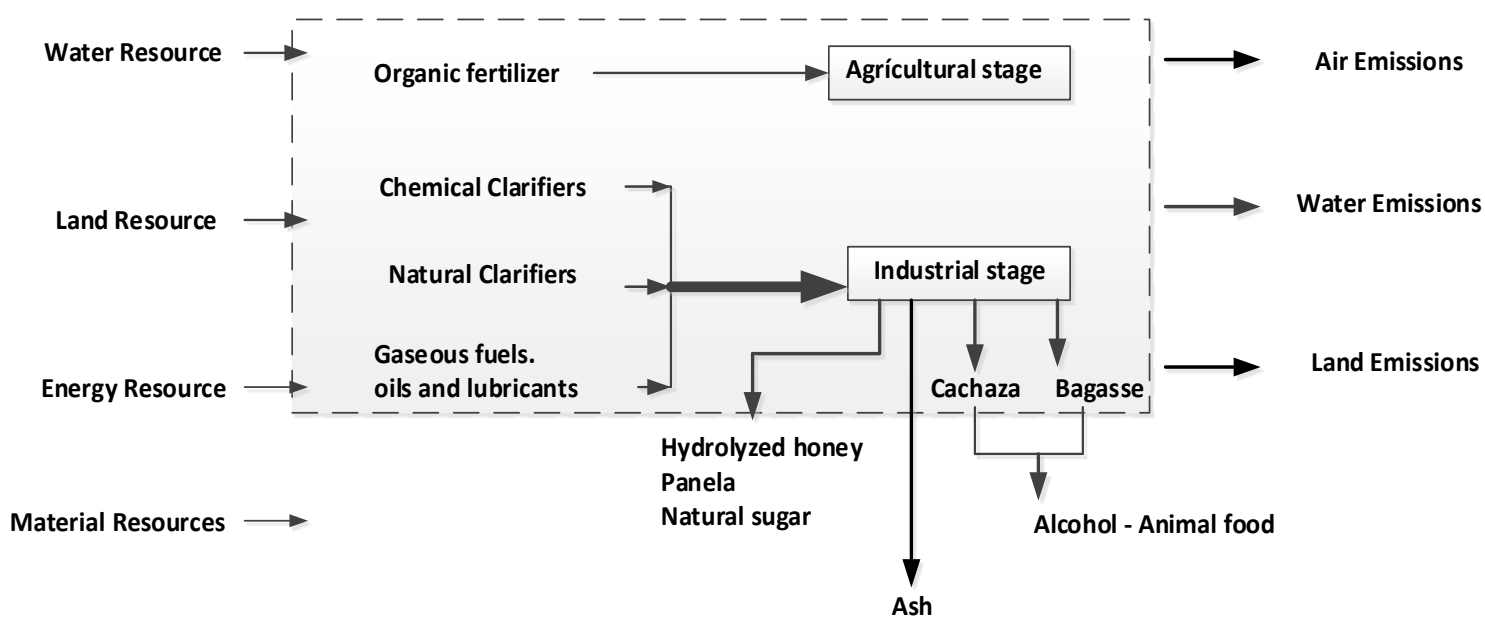

Fig.1: Limits for the production of panela, natural sugarcane and hydrolyzed honey

\section{RESULTS}

As a result of the intensification and diversification, the efficiency of the production of the sweeteners with and without aromas in the different variants got scores between 13.24 and $14.92 \%$, higher than those calculated in the current panela industry, which are encouraging with respect to those reported in Colombia and India [30] [31]. It is noted that the scores are better for the variant where the hydrolyzed honey appears in the process. Figure 2 shows the diagram for obtaining three sweeteners.

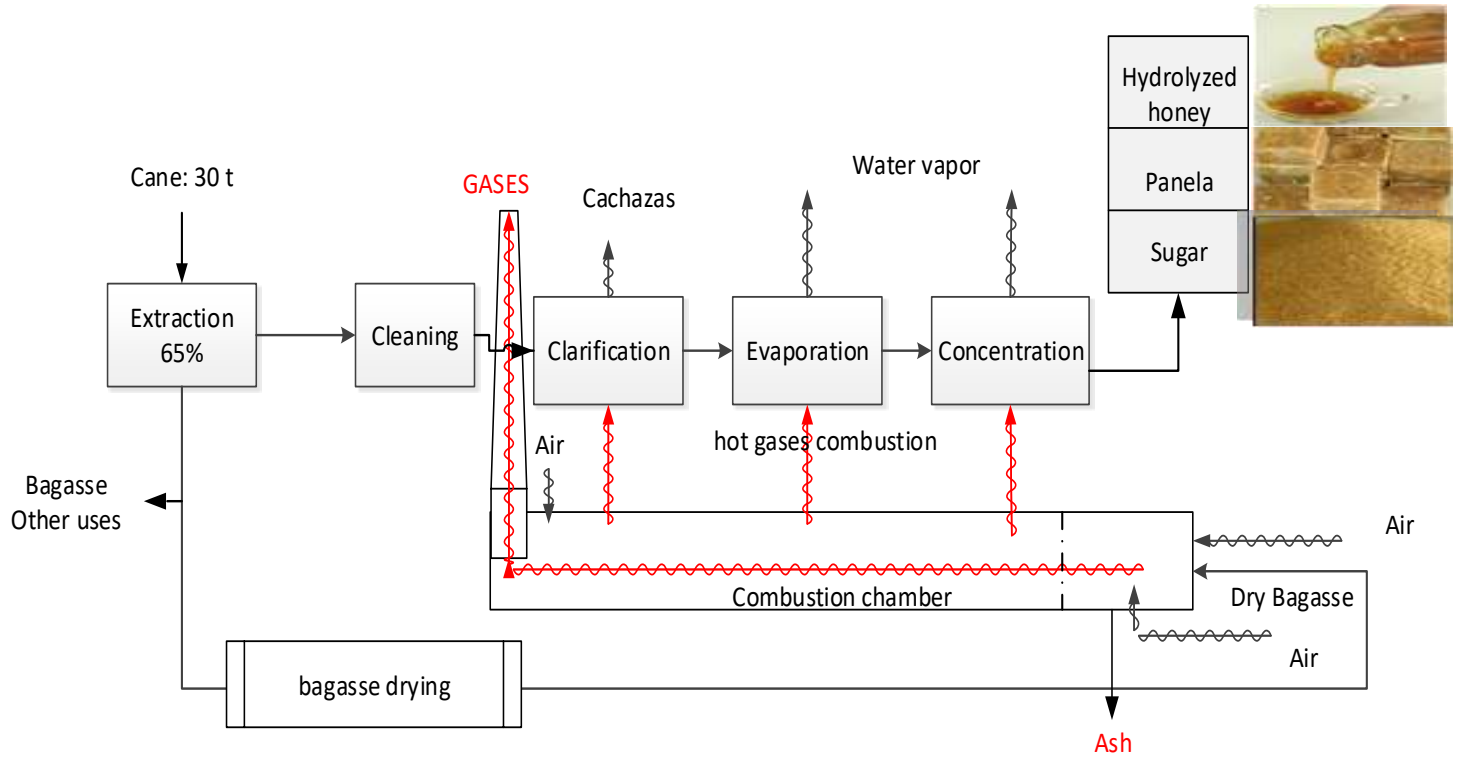

Fig.2: Diagram of the production process of hydrolyzed honey, panela and natural sugarcane.

The results of Figure 3 show that the major contribution to pollution occurs in the industrial stage, specifically in the production of honey, panela and natural sugar, being the two latter the most significant. 


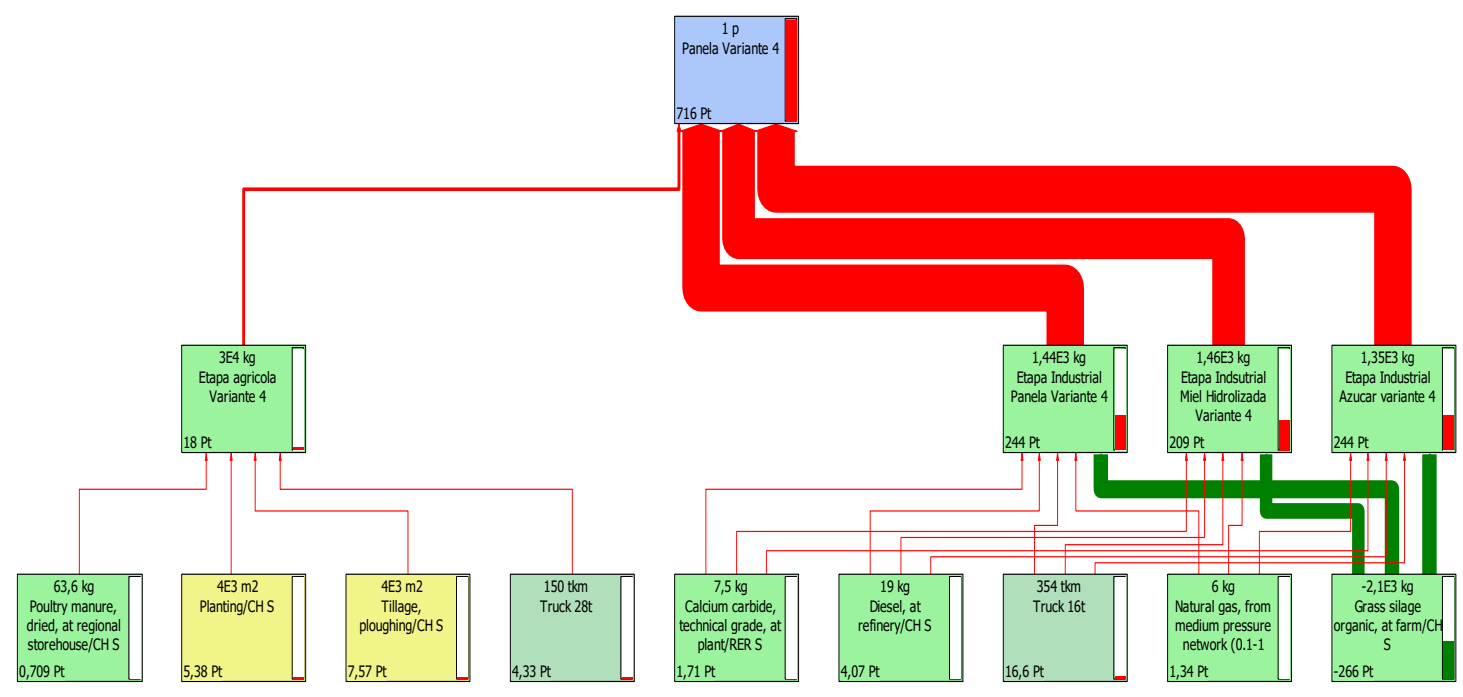

Fig.3: Impacts in the production variants

According to figure 4 of the industrial stage, the impact of inorganic respiration compounds is higher due to the use of diesel and bagasse as fuel in the combustion process. Unlike the industrial stage under current conditions, this variant significantly reduces the impact on the categories acidification - eutrophication, soil use, minerals, radiation, fossil fuels, ecotoxicity and climate change, which is attributed to the use of by-products as animal food. At the agricultural stage the impact is significant in the categories of fossil fuels, respiration of organic compounds, climate change, radiation, minerals and ecotoxicity.

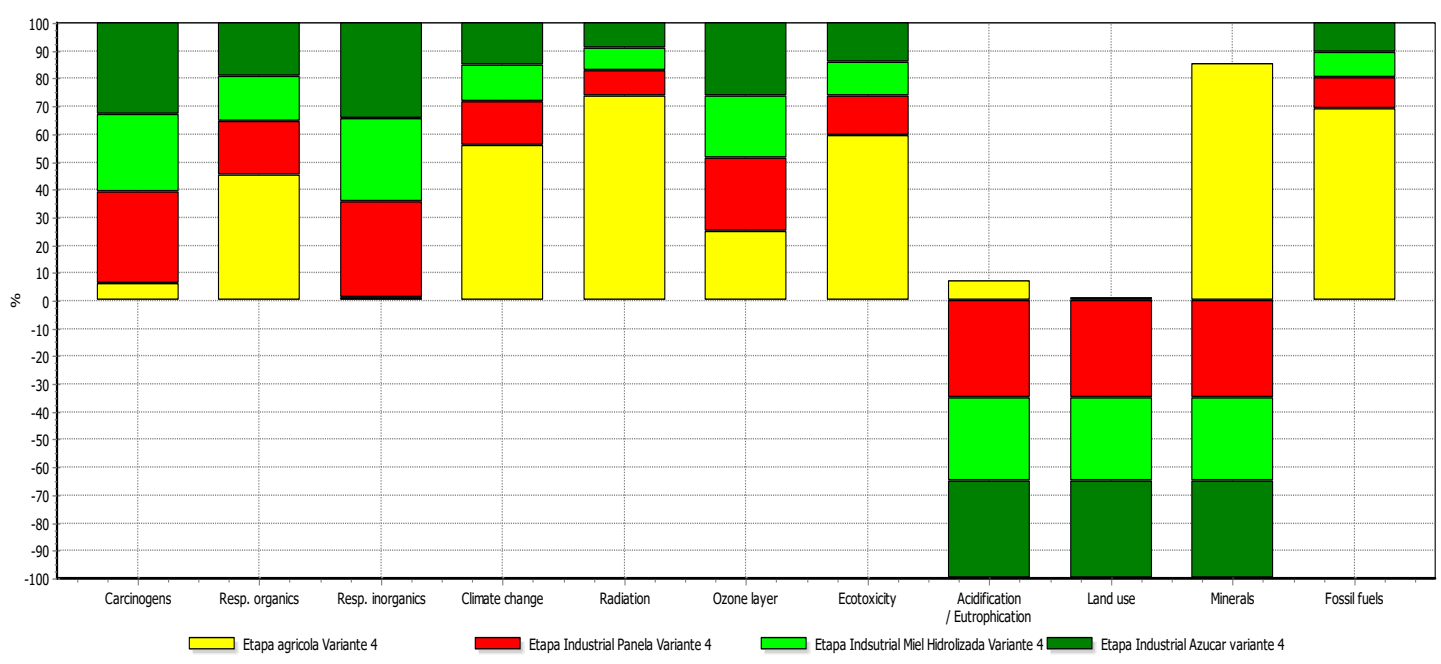

Analizando 1 p 'Panela Variante 4'; Método: Eco-indicator 99 (H) V2.08 / Europe El 99 H/A / Caracterización

Fig.4: Contribution of impact categories according to Eco-indicador 99

Figure 5 shows the comparison of the environmental profiles of the current variant with Variant 4, where the contribution is lower in the following impact categories: climate change, radiation, acidification / eutrophication, land use, minerals and fossil fuels. However, in the categories carcinogenesis, respiration of inorganic compounds and ozone layer, the results in variant 4 are higher. This is due to the fact that in this alternative more sugar cane is used, because three products have to be produced, therefore the amount of fuel increases, causing more air emissions. 


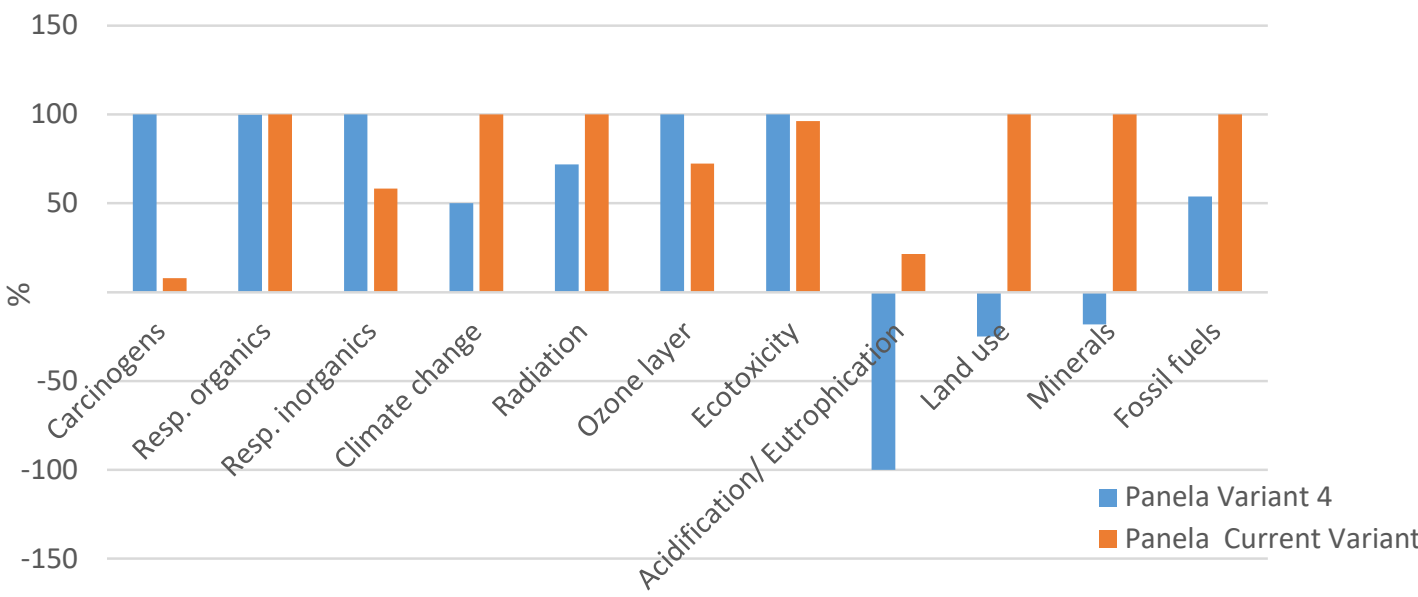

Method: Eco-indicator 99 (H) V2.08 / Europe El 99 H/A / Caracterization

Fig.5: Comparison of the environmental profiles of the Current Variant and Variant 4

A comparison of the total score of the current variant, where only panela is produced, and variant 4 , where three products are produced, (Figure 6) shows that the total impact in Variant 4 is greater, because of the increase in the amount of sugar cane processed (10 t / day), consequently the air emissions associated to the combustion processes are increased. However, this impact is conditioned to the production of three products, unlike the current variant where only panela is produced.

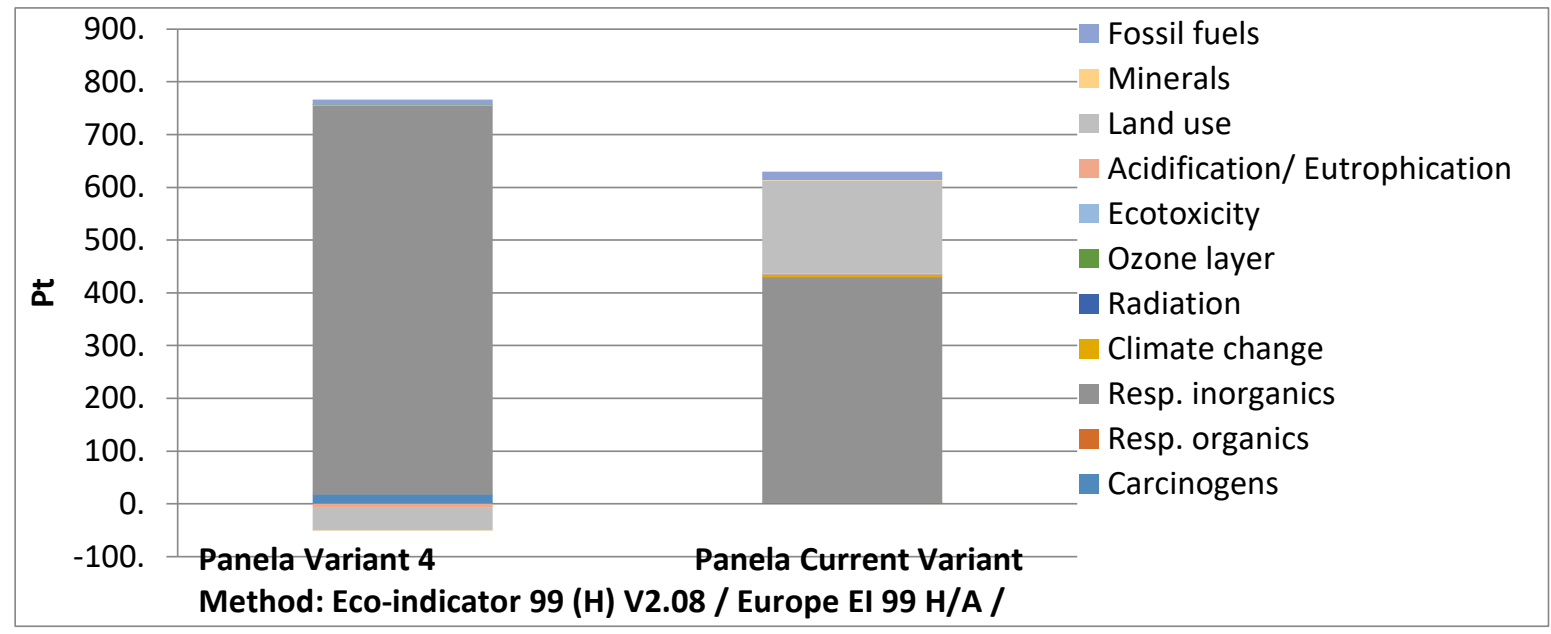

Fig.6: Comparison of the total impact of the Variant 4 with the Current variant

In figure 7, results from the comparison of the production of $1 \mathrm{~kg}$ of panela under current conditions with the production of $1 \mathrm{~kg}$ of a product in Variant 4, that considers in its percentages the production of honey, panela and natural sugar, evidence that the proposed variant is more feasible from the environmental point of view. 


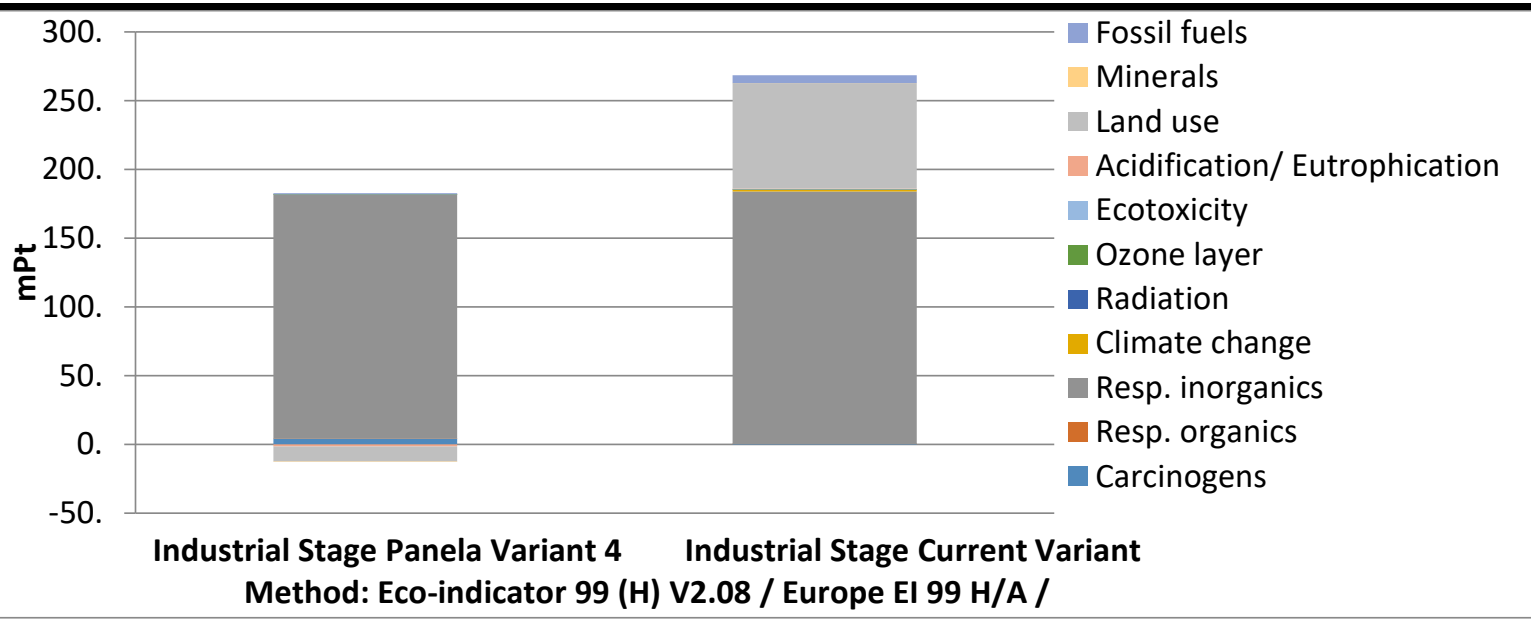

Fig.7: Comparison of the total impact of the Variant 4 with the Current variant per kilograms of the product

This shows that IP applied to the panela industry favors the development of new products as proposed in Variant 4, compared to the current Variant dedicated to the exclusive production of panela. It also optimizes processes and increases production capacity, taking advantage of byproducts and the alternative use of natural clarifiers. This ensures the use of the LCA methodology as a viable environmental assessment tool in this sector and allows this industry be categorized as low-impact industry [32].

\section{CONCLUSIONS}

The Life Cycle Analysis (LCA) is a viable concept useful as a design and planning tool in decision making, project execution and is increasingly used for the evaluation of environmental loads for the purpose of improvement and consequently with the environmental and economic benefits. It is feasible to intensify the panela industry, based on theoretical principles with technical results, through the incorporation of new production lines and combinations, depending on internal and external factors considered by the industry.

The environmental assessment of the panela industry carried out through the LCA methodology confirms that the industrial stage is the one with greater contribution in all the impact categories. The impact of inorganic respiration compounds is higher, due to the use of diesel and bagasse in the combustion processes.

Of all the alternatives of production, the variant for the elaboration of hydrolyzed honey is feasible and technically and economically favorable. Considering the aspects of diversification, Variant 4 is the one that responds to the interests of the producers, since it considers optimization criteria for making the intensification of a dynamic and competitive agroindustry more feasible. Therefore, it reveals the need for management with immediate application to provide solutions and ensure the progress and productivity of the panela industry for sustainability.

\section{REFERENCES}

[1] Quezada, W. 2015. Procedimiento para la intensificación y reconversión de instalaciones paneleras. Tesis presentada en opción al Grado Científico de Doctor en Ciencias Técnicas. Especialidad Ingeniería Química. Universidad Central Marta Abreu de Las Villas. Cuba, p.100.

[2] Kiran Y. Shiralkar, Sravan K. Kancharla, Narendra G. Shah, Sanjay M. Mahajani. 2013. Energy improvements in jaggery making process. Energy for Sustainable Development. ESD-00285; No. of pages: 13; 4C: ELSEVIER. India.

[3] Kumar, A. 2010. An Empirical Study on Gur (Jaggery) Industry. Indian Institute of Management Ahmedabad380 015. India. W.P. No. 2010-12-03, http://ssrn.com/abstract=1783403. (Accessed 03 January 2016).1-19.

[4] FAO (2013). Agroindustria para el desarrollo. Food and agricultural organization, Roma. http://www.fao.org/docrep/017/i3125s/i3125s00.pdf. (Accessed 02 January 2016). 283.

[5] Quezada, W., et al 2016. Cane Honey: Process, Quality and Harmlessness. International Journal of Engineering Research. IJER. Volume No.5, Issue No.7, pp: 589-593. ISSN: 2319-6890) (online), 2347-5013(print).

[6] Quezada, W., et al 2017. Environmental Impact Evaluation of the Industry of Panela by Life Cycle Analysis. International Journal of Environment, Agriculture and Biotechnology (IJEAB). Vol-2, Issue1, Jan-Feb 2017. ISSN: 2456-1878. 
[7] Goedkoop Mark; Effting Suzanne; and Collignon Mercel, 1999. Manual Práctico de ecodiseño. Anexo Eco-indicador 99. Método para evaluar el impacto ambiental a lo largo del ciclo de vida. Holanda, p, 5. Pdf.

[8] Simon B.; Robert F.; Andreas G. \& Henrik H. 2009. An industrial view of process intensification. Chemichal Engineering and Processing 48 329-332.

[9] Lutz, P.; Gani, R. \& Woodley, J. M. 2010. Process intensification: A persperctive on process synthesis. Chemichal Engineering Processing 49 (2010) 547-558.

[10] Pérez, A. D. (2011). La necesidad de la intensificación de procesos en la industria química. Universidad Nacional de Colombia.

[11] Arteche Amaya and Ipiñazar, Enrique. 2014. Intensificación de Procesos para una Industria Química más sostenible. Área de Biorrefinería y Valorización de Recursos. OTECNALIA RESEARCH \& INNOVATION. All rights reserved. Barcelona, España.

[12] González, E. et al. 1993. Aplicación del Análisis Complejo de Procesos en la intensificación de instalaciones de la Industria Química en países en vías de desarrollo. UCLV.

[13]Zaror C. 2000. Introducción a la ingeniería ambiental para la industria de procesos. Universidad de Concepción. Chile,

[14] Kiel, F.J. 2007. Modeling of Process Intensification. Book. WILEY-VCH Verlag GmbH \& Co. KGaA, pp.1-12.

[15] Freund, H. \& Sundmacher, K. (2008). Towards a methodology for the systematic analysis and design of efficient chemical processes. Chemical Engineering and Processing 47. 2051-2060.

[16] Reay, D; Ramshaw, C. \& Harvey, A. 2009. Process intensification. Engineering for Efficiency, Sustainability and Flexibility. Book of IChemE.

[17] Wiroon Tanthapanichakoon. 2013. Accelerating Process and Product Development. Chemical Engineering. February 2013, p. 48.

[18] Arne Remmen; Allan Astrup Jensen; Jeppe Frydendal. 2007. Life Cycle Management A Business Guide to Sustainability. UNEP. United Nations Environment Programme, EEUU, p.12, 17.

[19] Sánchez O. y Cardona C. 2007. Análisis de ciclo de vida y su aplicación a la producción de bioetanol: Una aproximación cualitativa. REVISTA Universidad EAFIT. Vol. 43. No. 146. 2007. pp. 59-79
[20] Daniele Willer C., Brito L. and Alves da Silva C. 2013. Avaliação do ciclo de vida no Brasil: uma investigação nas principais bases científicas nacionais. Produção, V. 23, $\mathrm{N}^{\circ}$. 2, p. 436-447, abr./jun. 2013. http://dx.doi.org/10.1590/S0103-65132012005000037

[21] Ruíz Nilbia 2007. Aplicación del Análisis de Ciclo de Vida en el estudio de diferentes ambientes de diferentes procesos Avanzados de oxidación. Tesis doctoral. Barcelona, España, p.11. 184 páginas.

[22] Suppen Nydia and van Hoof Bart. 2005. Conceptos básicos del Análisis de Ciclo de Vida y su aplicación en el Ecodiseño. México, p.1. 1-40.

[23] CMPL. 2002. ISO 14040, Life cycle analysis, Geneva, International Standards Organization. Centro Mexicano de Producción más Limpia, www.cmpl.mx, 2002.

[24] Uche Javier; Raluy Gemma; Serra Luis and Valero Antonio. 2014. Aplicación de la metodología de análisis de ciclo de vida (ACV) para la evaluación ambiental de desaladoras. Artículo Científico. España.

[25] UNEP. 2004. ¿Por qué Adoptar un enfoque de ciclo de vida?. Life Cycle. Una publicación de las Naciones Unidas. ISBN: 92-807-24500-9, p. 19.

[26] IICA. 2009. Informe anual. La contribución del ICCA al desarrollo de la agricultura y las comunidades rurales en Ecuador.

[27] Boucher, F. \& Muchnik, J. 1995. Agroindustria rural, Recursos Técnicos y Alimentación. Serie Agroindustria Rural CIRAD-CIID-IICA No. 1 ISBN 92-9039-2745.

[28] Delgado, F. \& Escobar, C. 2009; Innovación tecnológica, soberanía y seguridad alimentaria. Editor Agruco-Captured. Bolivia. ISBN: 978-99954-1-190-9.

[29] Ministerio del ambiente. 2014. Catálogo de categorización nacional ambiental CCAN. Anexo 1. http://www.cip.org.ec/attachments/article/2285/ANEX O\%201\%20CCAN.pdf.

[30] Velásquez, H. I.; Agudelo A. F. \& Álvarez, J. I. 2005. Mejorando la producción de panela en Colombia. Vol. 21, Núm. 1, Junio 2005, Energía en la finca.

[31] Kiran, S.; Sarvan, K.; Narendra, S. \& Sanjay M. 2013. Energy improvements in jaggery making process. Energy for sustainable Development. ELSEVIER. India.

[32]CCAN. 2014. Categorización ambiental Nacional según acuerdo Ministerial 006. Cámara de Industrias y Producción CCAN. Boletín de ambiente y seguridad industrial \# 25. Quito. Ecuador. 